\title{
Pemberdayaan Kelompok Wanita Tani Desa Patondonsalu Kecamatan Maiwa, Kabupaten Enrekang
}

\author{
Empowerment of Women Farmers Group in Pattondonsalu \\ Maiwa Distric, Enrekang Regency \\ ${ }^{1)}$ Jamilah, ${ }^{2)}$ Budiman, ${ }^{3)}$ Munawwarah S. Mubarak, ${ }^{4)}$ Muh. Fadhlullah Mursalim \\ ${ }^{1,2}$ Fakulta Peternakan, ${ }^{3}$ Fakultas Ekonomi, ${ }^{4}$ Fakultas Kedokteran \\ Universitas Hasanuddin \\ Jl. Perintis Kemerdekaan KM.10 Tamalanrea, Makassar \\ *email: jamilah.doma@unhas.ac.id
}

DOI:

10.30595/jppm.v5i1.9312

Histori Artikel:

Diajukan:

27/12/2020

Diterima:

$10 / 01 / 2022$

Diterbitkan:

18/02/2022

\section{ABSTRAK}

Desa Pattondon Salu merupakan desa yang potensial untuk dikembangkan karena letaknya yang strategis berada di jalan poros kabuapten. Jumlah penduduk didesa ini di dominasi oleh perempuan sekitar $51 \%$, kondisi tersebut membuat peran wanita sangat strategis. Salah satu cara untuk meningkatkan ekonomi keluarga adalah pemberdayaan kelompok wanita tani (KWT) dan meningkatkan pengetahuannya melalui teknologi tepat guna yang mudah dimengerti dan dilaksanakan. Metode pendekatan tim menyelesaikan masalah disepakati bersama dengan semua anggota kelompok (mitra) meliputi penyuluhan, latihan dan kunjungan (Laku), pendidikan sekolah lapang (SL), demplot, pembimbingan dan pendampingan, learning by doing. Kegiatan dilaksanakan selama 8 (Delapan) bulan dengan rencana kegiatan memecahkan persoalan meliputi: pembagian tugas pekerjaan, pelaksanaan program kerja anggota kelompok, pengadaan sarana prasarana, pemanenan produksi, pemasaran, monitoring dan evaluasi, seminar dan pelaporan. Hasil pengabdian ini yaitu diadakakan pertemuan dengan stakeholder untuk membahas permasalahan KWT, selanjutnya diadakan sosialisasi program yang dilaksanakan dan dilanjutkan dengan pelatihan keterampilan berupa pembuatan stik sawi. Selain itu juga dilaksanakan demplot untuk penanaman sayuran dan tanaman hias. Dari pelaksanaan program ini dapat disimpulkan bahwa Kelompok wanita tani mampu menerapkan materi yang disuluhkan, mampu mengolah sawi menjadi stik sawi sehingga nilai jualnya meningkat dan juga memanfaatkan pekarangannya untuk menanam sayuran dan tanaman hias.

Kata kunci: KWT; Penyuluhan; Stik Sawi; Sayuran

\begin{abstract}
Pattondon Salu Village is a village that has the potential to be developed because of its strategic location on the district axis road. Women dominate the population in this village, around 51\%; this condition makes the role of women very strategic. One way to improve the family economy is to empower the Women Farmers Group (WFG) and increase their knowledge through an appropriate technology that is easy to understand and implement. The team approach method for solving problems was mutually agreed upon with all group members (partners), including counseling, training, visits, field school education, demonstration plots, coaching and mentoring, learning by doing. The activity was carried out for 8 (eight) months with a problem-solving activity plan, including division of work tasks, implementation of work programs for group members, procurement of infrastructure, production harvesting, marketing, monitoring and evaluation, seminars, and reporting. The
\end{abstract}


Jamilah, Budiman, Munawwarah S. Mubarak, Muh. Fadhlullah Mursalim

Pemberdayaan Kelompok Wanita Tani Desa Patondonsalu Kecamatan Maiwa, Kabupaten Enrekang

result of this service was that a meeting with stakeholders was held to discuss KWT problems, then socialization of the program was carried out and continued with skills training in the form of making mustard sticks. In addition, demonstration plots were also carried out for planting vegetables and ornamental plants.

From the implementation of this program, it can be concluded that the Women Farmers Group can apply the taught material, process mustard greens into mustard sticks so that the selling value increases, and utilize their yard to grow vegetables and ornamental plants.

Keywords: Women Farmers Group; Counseling; Mustard Sticks; Vegetables

\section{PENDAHULUAN}

Secara administratif
Pattondonsalu berada dalam $\begin{array}{r}\text { Desa } \\ \text { wilayah }\end{array}$
Kecamatan Maiwa, Kabupaten Enrekang,
Provinsi Sulawesi Selatan. Desa ini dari 4
(empat) dusun yaitu : Dusun Jambu, Dusun
Salokaraja, Dusun Mattirowali, dan Dusun
Santunan, dengan luas wilayah 28.610 Km2.
Desa Pattondonsalu terletak $\pm 38 \mathrm{Km}$ dari kota
Enrekang, atau $\pm 5 \mathrm{Km}$ dari Ibukota
Kecamatan dan $\pm 198 \mathrm{Km}$ dari Makassar
(Maryam, 2017).

Masyarakat di desa Salokaraja memiliki ciri khas yang unik yaitu pekarangan rumah yang luas yang bisa mencapai $10 \times 10 \mathrm{~m}$ tiap rumah, belum lagi kolong rumah yang juga kosong karena rumah di desa tersebut berbentuk rumah panggung. Keberadaan pekarangan rumah dan ibu rumah tangga yang tidak produktif dapat dimanfaatkan untuk meningkatkan pendapatan keluarga dengan memanfaatkan pekarangan rumah. Pemerintah desa Pattondonsalu melalui Ketua Darmawanita Telah membentuk Kelompok Wanita Tani (KWT) namun kelompok tersebut hanya terbentuk tanpa program yang jelas dan belum menunjukkan manfaat yang signifikan bagi anggotanya. Pada dasaranya KWT menempatkan perempuan sebagai pelaku usaha tani, namun peran perempuan menjadi ganda yaitu juga sebagai Ibu Rumah Tangga yang menjai tugas utamanya, sehingga produktivitasnya tidak bisa menyamai peteni pria yang memanfaatkan semua waktunya untuk bertani. Peran sebagai IRT dan KWT dapat berjalan beriringan tanpa saling mengganggu jika KWT yang ada mengelola pekarangan rumah menjadi kebun hijau dengan mengintegrasikan peternakan dan pertanian, yaitu dengan membuat penanaman sayuran, toga (tanaman obat keluarga), tanaman hias dan buah buahan di pekarangan serta memelihara ayam buras.

Wanita adalah aktor kunci rumah tangga, dalam pencapaian ketahanan pangan rumah tangganya. Salah satu alasannya adalah ketahanan pangan merupakan bagian dari peranan reproduktif mereka. Kenyataan bahwa fungsi rumah tangga sebagai unit konsumsi, peranan reproduktif wanita berkembang pada ketahanan pangan dan nutrisi rumah tangganya secara keseluruhan dan tidak terbatas hanya pada anak-anak mereka. Produksi ketahanan pangan dan nutrisi rumah tangga terdiri dari beberapa aktivitas yang saling terkait, yaitu budidaya tanaman pangan, pengadaan pangan, pengumpulan dan penukaran, persiapan dan pengolahan pangan, dan akhirnya distribusi pangan. Hampir semua aktivitas ini merupakan tugas wanita (Mulyani dan Madamdari, 2012). Ervinawati (2015) menyatakan bahwa memasuki era globalisasi dan semakin meningkatnya kesadaran dan pemerataan peluang berusaha maka peranan atau emansipasi wanita untuk memiliki harkat dan martabat yang sama dengan pria semakin meningkat, sehingga wanita juga berperan dalam menyokong ekonomi keluarga. Penghasilan masyarakat di desa ini yang bermata pencaharian sebagai petani hanya sekitar Rp. 700.000,-/bulan. Wanita tani nantinya dapat menambah penghasilan, adapun dari hasil yang di dapat tidak hanya buah dan sayuran, akan tetapi di tekankan pada peningkatan kreatifitas dan pengetahuan dalam membudidayakan dan mengolah tanaman sayuran.Pendahuluan ditutup dengan tujuan pengabdian.

\section{METODE}

Metode pendekatan yang ditawarkan untuk menyelesaikan masalah oleh pelaksana 
Jamilah, Budiman, Munawwarah S. Mubarak, Muh. Fadhlullah Mursalim

Pemberdayaan Kelompok Wanita Tani Desa Patondonsalu Kecamatan Maiwa, Kabupaten Enrekang

disepakati bersama dengan semua anggota kelompok (mitra). Metode meliputi penyuluhan (Van den ban, 2008), Latihan dan kunjungan (Laku), demplot, pembimbingan dan pendampingan, learning by doing. Metode penyuluhan yang digunakan adalah metode penyuluhan partisipatif, dimana Metode penyuluhan pertanian partisipatif yaitu masyarakat berpartisipasi secara interaktif, analisis-analisis dibuat secara bersama yang akhirnya membawa kepada suatu rencana tindakan. Partisipasi di sini menggunakan proses pembelajaran yang sistematis dan terstruktur melibatkan metode-metode multidisiplin, dalam hal ini kelompok ikut mengontrol keputusan lokal (Suwandi, 2006). Sistem Kerja LAKU adalah pendekatan yang memadukan antara pelatihan bagi penyuluh dan ditindaklanjuti dengan kunjungan berupa pendampingan (Kamaruzzaman, 2016).

\section{HASIL DAN PEMBAHASAN}

1. Pertemuan dengan stakeholder

Pertemuan dengan stakeholder awalnya dijadwalkan bertemu dengan Kepala Desa, namun saat kami berkunjung, beliau sedang ada acara di Kabupaten. Beliau kami kontak melalui telfon, dan secara lisan mengizinkan untuk dilaksanakannya sosialisasi pada kelompok tani yang akan diadakan keeseokan harinya.

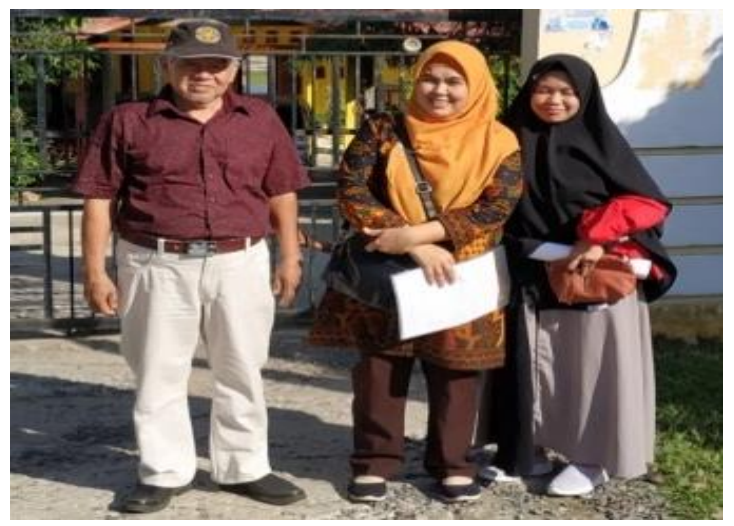

Gambar 1. Pertemuan dengan stakeholder

\section{Pelaksanaan Sosialisasi}

Sosialisasi dilaksanakan secara santai sambil membersihkan area yang nantinya akan dijadikan salah satu tempat untuk penanaman sayuran dan tanaman hias. Sosialisasi hanya memberiakan gambaran mengenai program apa yang akan dilaksanakan dan juga belum dihadiri oleh RT karena acara kami adakan soreh hari dan sebagian besar petani belum pulang dari sawahnya.

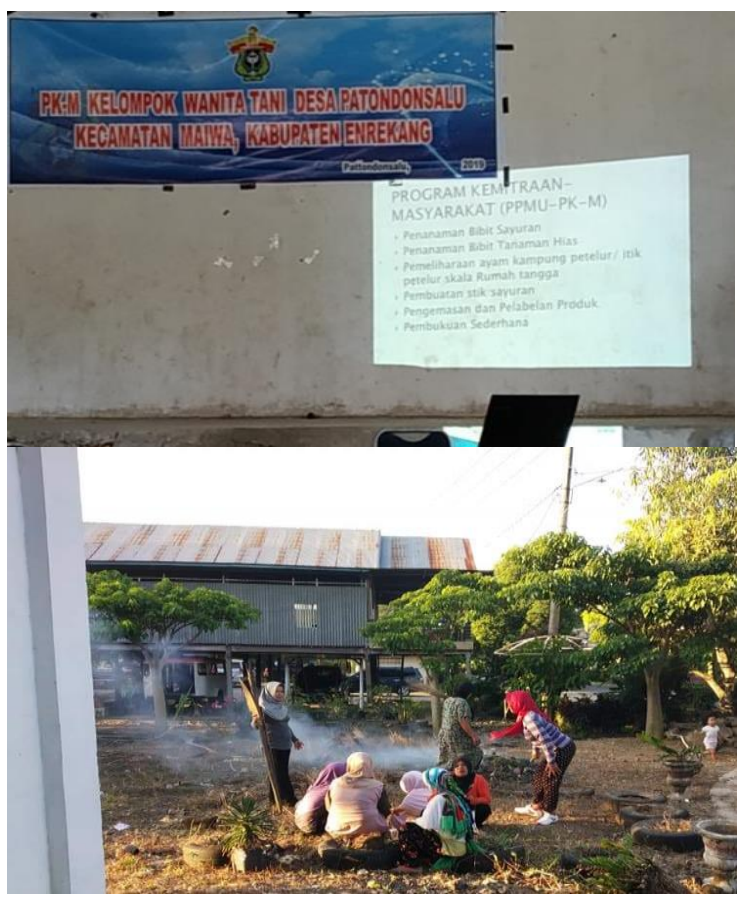

Gambar 2. Pelaksanaan Sosialisasi

\section{Pelaksanaan Penyuluhan}

Penyuluhan yang dilaksanakan meliputi pembuatan stik sayuran, manajemen keuangan, labeling dan packaging produk, dan potensi penanaman tanaman hias. Antusiasme warga sangat tinggi dan harapan mereka pada program ini juga sangat tinggi. Hanya saja yang sedikit membuat sulit, adalah ketika ketua kelompok tani menetapkan dan membagi tim untuk pembuatan stik sayuran, pemeliharaan ayam buras, penanaman tanaman hias dan penanaman sayuran.

Keegoisan mulai muncul dan ada beberapa anggota yang ingin memiliki semua item tersebut, sementara tim pengabdian tidak dapat memfasilitasi semua permintaan tersebut. Awal pemaparan program pada saat sosialisasi sudah disampaikan mengenai program dan tata cara pelaksanaannya. Manusia memang terdiri dari berbagai pemikiran dan perbedaan sehingga hal tersebut sangat wajar.

Kejadian tersebut termasuk dalam dinamika kelompok, meskipun ada keegoisan yang kadng muncul namun mereka tetap dan bersatu untuk mencapai tujuan bersama. Menurut 
Jamilah, Budiman, Munawwarah S. Mubarak, Muh. Fadhlullah Mursalim

Pemberdayaan Kelompok Wanita Tani Desa Patondonsalu Kecamatan Maiwa, Kabupaten Enrekang

Samsudin (1987) menyebutkan bahwa dinamika kelompok merupakan aktivitas untuk menanggapi tugas yang timbul karena adanya tantangan lingkungan dan tantangan kebutuhan, antara lain tuntutan untuk meningkatkan produktivitas usahatani. Suatu kelompok dikatakan dinamis jika interaksi sesama anggota lebih kuat dibandingkan interaksi dengan pihak luar kelompoknya. Jika semakin kuat interaksi di antara petani anggota, maka semakin kompak kelompok tersebut sehinggga mudah mencapai tujuan.

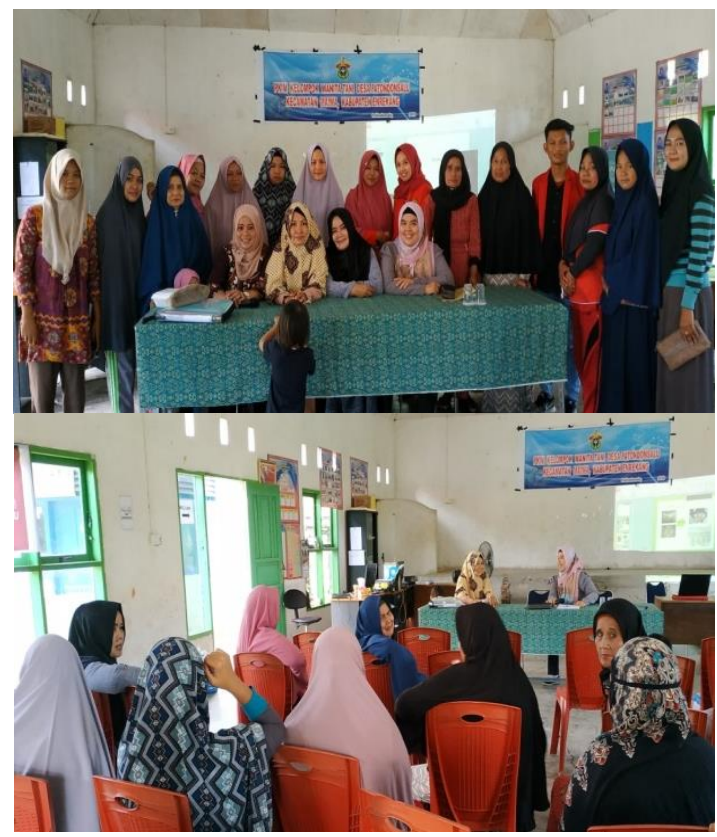

Gambar 3. Pelaksanaan Penyuluhan

\section{Pelatihan Pembuatan Stik Sawi}

Salah satu pelatihan yang diberikan adalah pembuatan stik sawi, untuk meningkatkan pendapatan anggota kelompok tani. Selain itu pembuatan stik ini dapat menjadi pengetahuan baru yang bermanfaat sebagai jajanan sehat yang bisa dikonsumsi oleh anggota keluarga untuk meningkatkan nilai gizi masyarakat. Menurut Febry, 2010 Makanan jajanan selain berfungsi sebagai makanan selingan, juga berperan sebagai sarana peningkatan gizi masyarakat.
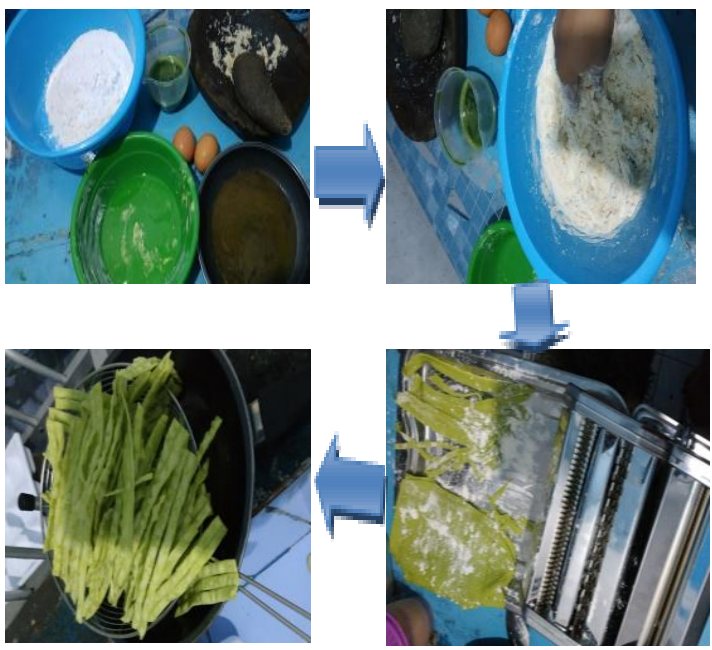

Gambar 4. Pelatihan Pembuatan Stik Sawi

Pelatihan ini memberikan efek positif pada anggota KWT, mereka merasa mendapat ilmu baru dan juga langsung menerapkannya. Stik sawi ini membuatnya hanya membutuhkan sedikit modal karena bahannya hanyalah terigu, tapioka, telur, sawi, garam dan bawang putih serta minyak untuk menggoreng.

Pada saat monitoring ke KWT setelah pelatihan kami mendapati bahwa anggota KWT mulai memanfaatkan ilmu yang kami berikan, salah satunya dengan membuat stik sawi untuk dijual. Meskipun usaha yang KWT lakukan masi skala kecil, namun dapat menambah keuangan keluarga. Salah satu usaha yang mereka lakukan adalah menjual jajanan sehat ini di lapangan yang berdampingan dengan sekolah dasar, hal ini memberikan implikasi positif karena selain menambah penghasilan juga menyediakan jajanan yang sehat dan bebas pengawet untuk anak sekolah dasar.

\section{Penanaman Sayuran dan Bunga}

Tim PKM juga meberikan bibit dan fasilitas untuk memelihara sayuran dan bunga. Sayuran yang mereka hasilkan kebanyakan masi untuk skala konsumsi dan juga dibuat keripik. Perilaku yang unik dari KWT ini adalah perilaku saling berbagi, sayuran yang mereka panen awalnya direncanakan untuk dijual agar meningkatkan pendapatan, namun mereka lebih memilih memberikan sayuran ke tetangga, karena sudah menjadi tradisi 
tanaman disekitar rumah bisa diminta ataupun diberikan ke tetangga sekitar.

Tanaman yang berhasil dikomersialkan hanyalah bunga, pembelinya biasa berasal dari warga di kabupaten yang bersebelahan dengan kabupaten Enrekang. Bunga ini memberikan efek positif ke masyarakat karena dapat memperindah halaman, memberikan rasa nyaman ketika dipandang dan juga mendatangkan hasil apabila dijual.

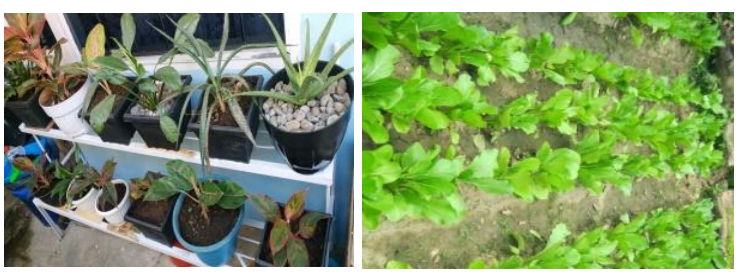

Gambar 5. Penanaman Sayuran dan Bunga

\section{SIMPULAN}

Berdasarkan pengabdian yang telah dilakukan dengan evaluasi di akhi kegiatan dapat disimpulkan bahwa kelompok wanita tani mampu menerapkan materi yang disuluhkan. Selain itu KWT sudah mampu mengolah sawi menjadi stik sawi sehingga nilai jualnya meningkat.Program PKM ini juga dapat memanfaatkan pekarangannya untuk menanam sayuran dan tanaman hias

\section{DAFTAR PUSTAKA}

Agustiana, W. (2013, Oktober) Pekarangan Hijau Bersama Kelompok Wanita Tani Melati Diunduh dari : http://green. kompasiana.com/ penghijauan/ 2013/10/11/ pekarangan -hijaubersama- kelompok -wanita -tanimelati-599589.html.20 November 2018.

Badan Pusat Statistik (2017). Kabupaten Enrekang dalam Angka. BPS Kabupaten Enrekang.

Ervianti. V., Fatmawati, dan Indri, E. (2015) Peran kelompok wanita tani perdesaan dalam menunjang pendapatan keluarga. JPMIS. E101212004.
Fatmalina F. (2010) Kebiasaan jajan pada anak. Jurnal Ilmu Kesehatan Masyarakat. 1(2): 81-84

Kamaruzzaman. (2016) Penerapan Metode Komunikasi Oleh Penyuluh Pertanian Pada Kelompok Tani Gema Rifa 1 Desa Jamur Labu (Kecamatan Rantay, asceh Tamiang.

Mardikanto, T. (2003). Penyuluhan Pembangunan Pertanian. Surakarta : UNS Press.

Mulyani, A. dan Madamdari, A. M. (2012). Peran wanita tani dalam mewujudkan ketahanan pangan rumah tangga di kabupaten banyumas (studi kasus di kecamatan Cilongok). SEPA : 8 (2 ) 51 -18 .

Samsuddin. (1987) Dasar-Dasar Penyuluhandan Modernisasi Pertanian. Bina Cipta. Bandung.

Suwandi. (2006) Penyuluhan Partisipatif. Bogor: Cekza Blog.

Van Den Ban A.W. dan Hawkins, H.S.. (2008) Penyuluhan pertanian. Yogyakatra : Kanisius. 